\title{
Perancangan dan Perhitungan Sudu Turbin Angin Horisontal NACA 4412 Variasi Sudut Serang Menggunakan Simulasi BEM
}

\author{
Gian Roni Ignatius ${ }^{1}$, Agus Sugiri' ${ }^{1}$, Ahmad Su'udi ${ }^{1}$ \\ 1) Jurusan Teknik Mesin, Fakultas Teknik Universitas Lampung \\ Jln. Prof.Sumantri Brojonegoro No. 1 Gedung H FT Lt. 2 Bandar Lampung \\ Telp. (0721) 3555519, Fax. (0721) 704947 \\ email : gianroniignatus1997@gmail.com
}

\begin{abstract}
The need for electricity in Indonesia becoming increasingly part of people's needs. Fossil fuels such as oil and coal used as the main material for producing electrical energy the more limited availability, especially in its use of fossil fuels that pollute the environment. Wind energy is a renewable energy source that could potentially be developed. Wind energy is clean and does not pollute the environment in utilization into mechanical or electrical energy. The conversion of wind energy into electrical energy by converting this energy into mechanical rotation. In the wind energy utilization process made a tool to convert wind energy into electrical energy, that is wind turbines. Wind turbine or windmill is a tool for converting wind energy. Wind turbines transform kinetic energy into mechanical energy in the form of a round shaft. Shaft speed is then used to rotate the dynamo or a generator which produces electricity. The research was carried out on a horizontal axis wind turbine NACA 4412, diameter $1 \mathrm{~m}$, the number of blades 3 pieces and variations in wind speed $2-8 \mathrm{~m} / \mathrm{s}$. Results showed the greatest lift $\left(C_{L}\right)$ at $14^{\circ}$ angle of attack with a value of 1.583 . The driving force of the smallest $\left(C_{D}\right)$ at an angle of attack $-4^{\circ}$ to $2^{\circ}$ with a value of 0.008 . Value $C_{L}$ $/ C_{D}$ was found in the angle of attack of $6^{\circ}$ with a value of 93.057. The maximum power generated by 484.63 Watt. Wind speed, the number of blades, angle of attack and the election of the airfoil effect on the generated power.
\end{abstract}

Keywords : wind energy, wind turbines, airfoil NACA 4412.

\section{PENDAHULUAN}

Kebutuhan akan energi, khususnya energi listrik di Indonesia semakin berkembang menjadi bagian yang tak terpisahkan dari kebutuhan masyarakat sehari - hari. Bahan bakar fosil seperti minyak bumi dan batu bara digunakan sebagai bahan utama untuk menghasilkan energi listrik semakin langka (terbatas ketersediaannya), terlebih lagi dalam pemanfaatannya bahan bakar fosil tersebut menghasilkan polusi bagi lingkungan.

Energi angin merupakan salah satu sumber energi terbarukan yang berpotensi dikembangkan. Energi angin ini bersih serta tidak mencemari lingkungan dalam pemanfaatannya menjadi energi listrik atau mekanik [3].
Turbin angin merupakan alat untuk mengkonversi energy angin. Turbin merubah energy kinetik menjadi energy mekanik berupa putaran poros. Putaran poros kemudian digunakan untuk memutar dinamo atau generator yang akhirnya menghasilkan energi listrik.[4].

Oleh karena itu penelitian ini dilakukan untuk melihat potensi tenaga angin di desa Tegineneng, kec. Limau, kabupaten Tanggamus dan merancang sudu turbin angin yang paling optimal.Pengujian dilakukan pada turbin angin sumbu horisontal NACA 4412, berdiameter $1 \mathrm{~m}$, jumlah sudu 3 buah dan variasi kecepatan angina $2-8 \mathrm{~m} / \mathrm{s}$. 
Tujuan dari penelitian ini adalah sebagai berikut :

1. Menganalisa karakteristik aerodinamika diantaranya adalah gaya angkat $\left(\mathrm{C}_{\mathrm{L}}\right)$, gaya dorong $\left(\mathrm{C}_{\mathrm{D}}\right)$ serta perbandingan gaya angkat dan gaya dorong $\left(\mathrm{C}_{\mathrm{L}} / \mathrm{C}_{\mathrm{D}}\right)$.

2. Menganalisis koefisien daya $\left(\mathrm{C}_{\mathrm{P}}\right)$ yang paling optimal dengan variable kecepatan angina berbeda.

3. Menganalisis sudut serang airfoil yang paling baik untuk menghasilkan daya paling maksimum.

4. Menganalisis pengaruh kecepatan angin untuk menghasilkan daya paling maksimum.

\section{TINJAUAN PUSTAKA}

\section{A. Turbin Angin Poros Horisontal}

Turbin angin poros horisontal merupakan turbin angin yang terdiri dari sebuah menara dimana puncaknya terdapat generator listrik dan baling-baling yang berfungsi sebagai rotor serta menghadap arah angin. Turbin berukuran kecil diarahkan oleh sebuah baling-baling angin (baling-baling cuaca) yang sederhana, sedangkan turbin berukuran besar pada umumnya menggunakan sebuah sensor angin yang digandengkan ke sebuah servo motor. Sebagian besar memiliki sebuah gearbox yang mengubah perputaran kincir yang pelan menjadi lebih cepat berputar. Karena sebuah menara menghasilkan turbulensi di belakangnya, turbin biasanya diarahkan melawan arah anginnya menara.

\section{B. NACA (National Advisory Committee for Aeronautics)}

Airfoil NACA adalah suatu bentuk geometri yang telah ditetapkan oleh NACA dan merupakan standar dalam perancangan suatu airfoil. Sebenarnya penggunaan NACA airfoil itu sendiri biasa digunakan dalam dunia aeronautika sebagai sayap pesawat. Semakin berkembangya dunia teknologi saat ini penggunaan NACA airfoil diaplikasikan dalam pembuatan geometri dalam dunia pembangkitan [2].

Dalam penamaan dan penomoran model dari seri pada airfoil, NACA memiliki standar pengkodean yang telah ditetapkan seperti seri 1 angka, 2 angka, 4 angka, dan 5 angka. Seperti pemilihan airfoil NACA 4412 berbentuk simetris, pengertiannya sebagai berikut:

1. Angka pertama yaitu maksimum chamber pada chord line dalam seperseratus chord.

2. Angka kedua adalah posisi maksimum chamber pada chord line dalam sepersepuluh chord dari leading edge.

3. Dua angka terakhir adalah nilai maksimum thickness dalam seperseratus chord.

\section{Karakteristik Turbin Angin}

1. Tip speed ratio

Tip speed ratio adalah faktor yang sangat penting dalam desain turbin angin, yang didefinisikan sebagai rasio kecepatan tangensial pada ujung sudu dengan kecepatan angin aktual [1].

Dimana,

$$
T S R=\frac{\pi \cdot D \cdot n}{v}
$$

$$
\begin{aligned}
& \mathrm{D}=\text { diameter turbin }(\mathrm{m}) \\
& \mathrm{v}=\operatorname{kecepatan} \operatorname{angin}(\mathrm{m} / \mathrm{s}) \\
& \mathrm{n}=\text { putaran turbin }(\mathrm{rpm})
\end{aligned}
$$

2. Koefisien Daya $\left(\mathrm{C}_{\mathrm{P}}\right)$

Nilai koefisien momen (CM) berhubungan dengan penentuan daya turbin angin yang dapat diperoleh dari nailai koefisien daya (CP). Daya keluaran dari turbin angin berubah-ubah seiring dengan kecepatan putar dari turbin sehingga kinerja rotor biasanya ditunjukan dengan grafik antara koefisien daya terhadap tip speed ratio. Namun hal itu juga dapat ditunjukan dengan grafik koefisien momen terhadap tip speed ratio.

3. Teori blade element momentum (BEM)

Teori blade element momentum (BEM) untuk menghitung gaya dorong (thrust), daya, dan koefisien daya (CP) dengan parameter kecepatan udara, kecepatan putar, dan pitch angle dari sudu turbin angin yang berbeda-beda maka dapat menggunakan teori Blade Element Momentum (BEM) [5]. 
Jurnal FEMA, Volume 8, Nomor 2, Juni 2020

\section{METODE PENELITIAN}

\section{XFoil Direct Analysis}

Xfoil direct analysis yaitu mensimulasikan variasi sudut serang sudu turbin horizontal. Simulasi ini dilakukan untuk mendapatkan nilai dari gaya angkat $\left(\mathrm{C}_{\mathrm{L}}\right)$ terbesar, gaya dorong $\left(\mathrm{C}_{\mathrm{D}}\right)$ terkecil dan perbandingan gaya angkat dan gaya dorong $\left(\mathrm{C}_{\mathrm{L}} / \mathrm{C}_{\mathrm{D}}\right)$ terbesar.

\section{Rotor BEM Simulation}

BEM (blade element momentum) mensimulasikan momentum dari setiap elemen pada blade. Hasil dari dilakukan simulai BEM yaitu mendapatkan nilai torsi, tip speed ratio dan daya mekanik.

\section{HASIL DAN PEMBAHASAN}

\section{Hasil}

Tabel 1. Simulasi Variasi Sudut Serang

\begin{tabular}{|c|c|c|c|}
\hline $\mathrm{A}\left({ }^{\mathrm{O}}\right)$ & $\mathrm{C}_{\mathrm{L}}$ & $\mathrm{C}_{\mathrm{D}}$ & $\mathrm{C}_{\mathrm{L}} / \mathrm{C}_{\mathrm{D}}$ \\
\hline-8 & -0.338 & 0.027 & -12.558 \\
\hline-7 & -0.235 & 0.026 & -8.959 \\
\hline-6 & -0.131 & 0.025 & -5.143 \\
\hline-5 & -0.06 & 0.009 & -6.586 \\
\hline-4 & 0.042 & 0.008 & 5.095 \\
\hline-3 & 0.148 & 0.008 & 18.686 \\
\hline-2 & 0.257 & 0.008 & 33.862 \\
\hline-1 & 0.364 & 0.008 & 46.706 \\
\hline 0 & 0.474 & 0.008 & 60.744 \\
\hline 1 & 0.582 & 0.008 & 73.402 \\
\hline 2 & 0.69 & 0.008 & 86.35 \\
\hline 3 & 0.789 & 0.009 & 87.664 \\
\hline 4 & 0.885 & 0.009 & 93.887 \\
\hline 5 & 0.98 & 0.011 & 92.679 \\
\hline 6 & 1.08 & 0.012 & 93.057 \\
\hline 7 & 1.17 & 0.013 & 87.542 \\
\hline 8 & 1.273 & 0.014 & 92.646 \\
\hline 9 & 1.359 & 0.015 & 90.295 \\
\hline 10 & 1.429 & 0.017 & 84.385 \\
\hline 11 & 1.48 & 0.019 & 76.066 \\
\hline 12 & 1.533 & 0.022 & 68.447 \\
\hline 13 & 1.577 & 0.027 & 59.466 \\
\hline
\end{tabular}

\begin{tabular}{|l|l|l|l|}
14 & 1.583 & 0.034 & 46.525 \\
\hline 15 & 1.568 & 0.046 & 34.32 \\
\hline 16 & 1.524 & 0.062 & 24.674 \\
\hline 18 & 1.358 & 0.133 & 12.057 \\
\hline 19 & 1.358 & 0.143 & 8.826 \\
\hline
\end{tabular}

Tabel 2. Simulasi Torsi, CP dan Daya Turbin

\begin{tabular}{|c|c|c|c|c|}
\hline $\begin{array}{c}\text { Kecepatan } \\
(\mathrm{m} / \mathrm{s})\end{array}$ & $\begin{array}{c}\text { Kec } \\
\text { putar } \\
(\mathrm{rpm})\end{array}$ & $\begin{array}{c}\text { Daya } \\
\text { Turbin } \\
\text { (Watt) }\end{array}$ & $\mathrm{Cp}$ & $\begin{array}{c}\text { Torsi } \\
(\mathrm{Nm})\end{array}$ \\
\hline 2 & 102 & 7,58 & 0,47 & 0,71 \\
\hline 3 & 153 & 25,57 & 0,47 & 1,6 \\
\hline 4 & 204 & 60,57 & 0,47 & 2,84 \\
\hline 5 & 255 & 118,33 & 0,47 & 4,43 \\
\hline 6 & 306 & 204,45 & 0,47 & 6,39 \\
\hline 7 & 357 & 324,67 & 0,47 & 8,68 \\
\hline 8 & 408 & 484,63 & 0,47 & 11,35 \\
\hline
\end{tabular}

\section{Pembahasan}

Analisis Karakteristik Aerodinamika Koefisien Angkat $\left(\mathrm{C}_{\mathrm{L}}\right)$, Koefisien Dorong $\left(\mathrm{C}_{\mathrm{D}}\right)$ dan Perbandingan $\mathrm{C}_{\mathrm{L}} / \mathrm{C}_{\mathrm{D}}$. Dengan melakukan simulasi terhadap airfoil NACA 4412 menghasilkan nilai $\mathrm{C}_{\mathrm{L}}$ terbesar didapatkan pada $\alpha=14^{\circ}$ dengan nilai sebesar 1,583 . Nilai $C_{D}$ terkecil didapatkan pada $\alpha=-4$ sampai $2^{\circ}$ dengan nilai terkecil 0,008 . Nilai $C_{L} / C_{D}$ terbesar didapatkan pada $\alpha=6^{\circ}$ dengan nilai 93.057. Gaya lift dan drag merupakan besaran vector, dimana angka negative hanya menunjukkan arah dari gaya tersebut. Hasil simulasi tersebut di plot ke dalam grafik yaitu grafik sudut serang $\alpha$ vs $C_{L}, \alpha$ vs $C_{D}, \alpha$ vs $\mathrm{C}_{\mathrm{L}} / \mathrm{C}_{\mathrm{D}}$. Nilai $\mathrm{C}_{\mathrm{L}}$ semakin bertambah dan akan maksimal pada $\alpha=14^{\circ}$ yaitu sebesar 1,583 . Pada saat $\alpha=16^{\circ}$ sampai $19^{\circ}$ nilai $C_{L}$ menurun menjadi 1,524 dan 1,358. Hal ini terjadi pada keadaan stall. Efek stall terjadi ketika aliran yang melewati airfoil tidak berlanjut.

Semakin tinggi nilai $\mathrm{C}_{\mathrm{L}}$ menandakan kinerja airfoil semakin baik, tetapi disamping timbulnya gaya lift juga akan timbul gaya drag. Untuk nilai $\mathrm{C}_{\mathrm{L}}$ yang paling tinggi terjadi pada $\alpha$ $=14^{\circ}$ yaitu sebesar 1,583 namun $C_{D}$ yang 
dihasilkan juga besar yaitu 0,034 sehingga hal ini menyebabkan nilai $\mathrm{C}_{\mathrm{L}} / \mathrm{C}_{\mathrm{D}}$ lebih kecil yaitu 46,525 bila dibandingkan nilai $\mathrm{C}_{\mathrm{L}} / \mathrm{C}_{\mathrm{D}}$ pada $\alpha=$ $6^{\circ}$ dengan nilai 93.057. Hal ini disebabkan pada $\alpha=6^{\circ}$ udara secara berlanjut melewati airfoil meskipun nilai $\mathrm{C}_{\mathrm{L}}$ lebih kecil yaitu sebesar 1,08 namun nilai $C_{D}$ lebih kecil yaitu 0,012 .

Nilai $\mathrm{C}_{\mathrm{D}}$ terkecil terjadi pada sudut serang $\alpha=$ $4^{\circ}$ sampai $2^{\circ}$ yaitu sebesar 0,008 . Semakin kecil nilai $\mathrm{C}_{\mathrm{D}}$ maka kinerja airfoil semakin baik. Pada airfoil terdapat 2 macam gaya yang bekerja yaitu gaya angkat dan gaya dorong. Kinerja airfoil berhubungan terhadap besarnya perbandingan $\mathrm{C}_{\mathrm{L}}$ dengan $\mathrm{C}_{\mathrm{D}}$ yang disebut rasio glide.

Koefisien lift dan drag merupakan nilai yang sangat penting sebagai pertimbangan performasi dari airfoil yang akan dirancang. Simulasi variasi sudut serang yang paling baik untuk menghasilkan daya paling maksimum yaitu pada sudut serang $6^{\circ}$ dikarenakan aliran udara secara berlanjut melewati airfoil.

\section{KESIMPULAN}

Setelah melakukan analisis maka didapatkan nilai gaya angkat terbesar $\left(C_{L}\right)$ pada sudut serang $14^{\circ}$ dengan nilai sebesar 1,583. Pada sudut serang $-8^{\circ}$ sampai $14^{\circ}$ nilai gaya angkat mengalami kenaikan signifikan dikarenakan aliran angin berlanjut melewati airfoil. Nilai gaya dorong terkecil $\left(C_{D}\right)$ pada sudut serang $4^{\circ}$ sampai $2^{\circ}$ dengan nilai 0,008 . Nilai $C_{L} / C_{D}$ terbesar didapatkan pada sudut serang $6^{\circ}$ dengan nilai 93,057. Setelah melakukan analisis maka didapatkan nilai koefisien daya yang paling optimal adalah 0,47. Daya maksimum yang dihasilkan sebesar 484,63 Watt pada sudut serang $6^{\circ}$ dikarenakan pada sudut serang $6^{\circ}$ aliran udara secara berlanjut melewati airfoil. Parameter yang berpengaruh dalam menghasilkan daya antara lain kecepatan angin, torsi, sudut serang dan jumlah sudu.

\section{DAFTAR PUSTAKA}

[1] Castelli, M. 2011. The Darrieus Wind Turbine: Proposal for a new performance prediction model. Energy, 4919-4934.

[2] Erlangga, Gema Pandji. 2017. Studi Eksperimental Karakteristik Aerodinamik Airfoil Naca 4412 Dengan Variasi Kecepatan Aliran Udara. Departemen Teknik Fisika, Fakultas Teknologi, Industri Institut Teknologi Sepuluh Nopember, Surabaya.

[3] Kumar, Vedulla, 2016. Modeling and Analysis of Wind Turbine Blade with Advanced Materials by Simulation. Yuan Ze University.

[4] Nakhoda, Yusuf, 2015. Rancang Bangun Kincir Angin Sumbu Vertikal Pembangkit Tenaga Listrik Portabel. Institut Teknologi Nasional Malang.

[5] Natayuda, Gilar. 2017. Analisa Aerodinamika Dan Kinerja Turbin Angin Tipe Sumbu Horisontal. Universitas Jenderal Achmad Yani. 